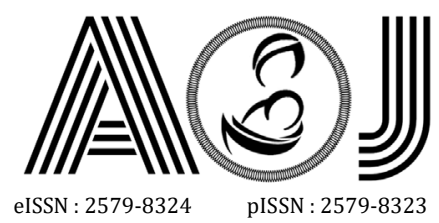

\title{
RESEARCH
}

\section{The correlation between Leptin Levels and Onset of Preeclampsia}

\author{
Roza Sriyanti ${ }^{1}$, Johanes C. Mose ${ }^{2}$, Masrul ${ }^{3}$, Netti Suharti ${ }^{4}$
}

Affiliations: 1. Postgraduate Biomedical Science, Faculty of Medicine, Andalas University, Dr. M. Djamil Central General Hospital Padang, Sub Division of Maternal Fetal Medicine, Obstetrics and Gynecology Department, Faculty of Medicine, Andalas University, Dr. M. Djamil Central General Hospital Padang; 2. Sub Division of Maternal Fetal Medicine, Obstetrics and Gynecology Department, Faculty of Medicine, Padjajaran University, Hasan Sadikin Hospital Bandung; 3. Nutrition Department, Faculty of Medicine, Andalas University, Padang; 4. Microbiology Department Microbiology, Faculty of Medicine, Andalas University, Padang

Correspondence: Roza Sriyanti, email: rozasyahrial@gmail.com, Hp:08126631253

\begin{abstract}
The purpose of this study is to find the correlation between leptin levels and the onset of preeclampsi. This study used a cross sectional comparative study design that conducted in May 2018 - April 2019 in the SMF / Obstetrics and Gynecology department of RSUP dr. M. Djamil Padang, RSUD Achmad Mochtar, RSUD Solok, RST Reksodiwiryo. We used consecutive sampling method which consists of 69 pregnant women who fulfill the inclusion and exclusion criteria. Leptin level tests were done using ELISA method. The average level of leptin in early-onset preeclampsia is found to be the highest when compared to the late-onset preeclampsia and normal pregnancy, $64.07 \pm 78.27 \mathrm{vs} .30 .46 \pm 31.99 \mathrm{vs}$. $16.61 \pm 24.49$. This differentiation is highly significant with the ANOVA statistical test $(p<0.05)$. There is a significant correlation between leptin levels with the onset of preeclampsia.
\end{abstract}

Keywords: preeclampsia early onset, preeclampsia late onset, leptin levels

\section{INTRODUCTION}

Preeclampsia is a multisystem disorder that occurs in about $2-10 \%$ of all pregnancies and most often causes maternal and fetal morbidity and mortality. ${ }^{1,2}$ The World Health Organization (WHO) reports that maternal mortality due to preeclampsia is $16 \%$ in developing countries. ${ }^{3}$ Preeclampsia can be divided into subclassifications: early onset preeclampsia (PEAD) and late onset preeclampsia (PEAL). The risk of maternal and fetal mortality in early onset preeclampsia (PEAD) is significantly greater than in late onset preeclampsia (PEAL), this is due to the fact that most of the severe placental perfusion and prematurity are impaired. ${ }^{4}$ Most newborns from PEAD pregnancies experience premature and impaired fetal growth (PJT). 5,6

PEAD occurs in $5-20 \%$ of all cases of preeclampsia associated with impaired fetal growth, fetal pathology, impaired uterine blood circulation, small placental size, preterm birth, and neonatal mortality and morbidity. Whereas PEAL is around $75-80 \%$ of the total cases of preeclampsia related to maternal mobility (such as metabolic syndrome, impaired glucose tolerance, obesity, dyslipidemia, chronic hypertension), with normal fetal weight and 


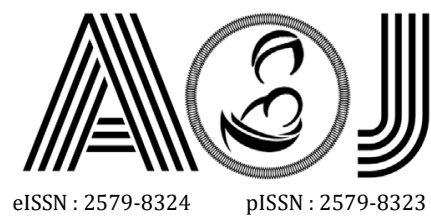

eISSN : 2579-8324
pISSN : 2579-8323

normal placental volume. ${ }^{7}$ Although the etiology of preeclampsia is not yet clear, abnormalities in the placenta are undoubtedly the pathogenesis of preeclampsia. The presence of abnormal placentation, including invasion of incomplete spirals of the trophoblast spirals, plays an important role as the pathogenesis and pathophysiology of preeclampsia. $^{1.8}$

Decreased placental perfusion will produce fetal-placental signals that affect maternal metabolism and physiology which will affect the course of nutrition and fetal growth. If a pregnant woman cannot tolerate the signal, it will cause preeclampsia. One of the signals of pregnancy is the hormone leptin. ${ }^{9}$ Recent studies have found that plasma leptin levels increase significantly in preeclampsia compared to normal pregnancy. ${ }^{10}$ Anim-Nayame et al. (2000) in his study showed that plasma leptin levels in early pregnancy increased significantly in preeclampsia with increasing maternal serum leptin concentrations and could be used as a marker of preeclampsia. ${ }^{11}$ Increased excessive leptin production is associated with endothelial dysfunction in preeclampsia women, which is produced by oxidative stress in human endothelial cells through a buildup of reactive oxygen species. ${ }^{12}$

There is still little research on the correlation of leptin levels with the onset of preeclampsia, especially in PEAD, where there has not been much research done and the results are controversial. The purpose of this study was to evaluate the correlation of leptin levels with the onset of preeclampsia, especially in PEAD.

\section{METHOD}

The study was conducted at Dr M. Djamil Hospital Padang and network hospitals. The study used a cross-sectional comparative study design by comparing the three study groups, namely early-onset preeclampsia, late- onset preeclampsia, and normal pregnancy to evaluated the serum levels of leptin in preeclampsia and normal pregnancy and to compare the difference between early-onset and late-onset preeclampsia. Preeclampsia is defined as hypertension with minimum criteria for systolic blood pressure $\geq 140 \mathrm{mmHg}$ and/or diastolic blood pressure $\geq 90 \mathrm{mmHg}$ after 20 weeks' gestation, and one or more proteinuria $\geq 300 \mathrm{mg} / 24$ hours or urine / creatinine protein ratio $\geq 30 \mathrm{mg} / \mathrm{dl}$ ( $1+$ urine dipstick), renal insufficiency, hematological abnormalities, liver disorders, cerebral disorders, pulmonary edema. The number of samples was 69 samples that met the inclusion criteria (single pregnancy women, gestational age $>20$ weeks, there were no severe medical abnormalities, no chorioamnionitis and no pregnancy with major congenital abnormalities), and exclusion criteria damage to blood samples during the research process and patients drop out during the research process).

Patients who meet the inclusion and exclusion criteria will be interviewed to obtain characteristic data including name, age, identity number, address, contact number, history of 


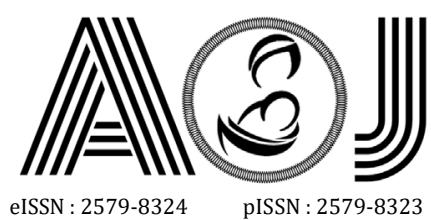

eISSN : 2579-8324
pISSN : 2579-8323

Ruang Redaksi Andalas Obstetrics and Gynecology Journal, Lantai 3 PPDS Obstetri dan Ginekologi Universitas Andalas, RSUP DR. M. Djamil Padang, Jl. Perintis Kemerdekaan Padang, Sumatera Barat 25127

pregnancy, the first day of the last day or ultrasound examination to assess gestational age. The size of the samples is calculated according to the simple formula to estimate the proportion of a population. The sampling formula used in unpaired numerical comparative research. The sampling technique is done by the consecutive method, i.e. the samples are taken sequentially. By the inclusion criteria and exclusion until the required number of samples is fulfilled. After the patient signed a letter of informed consent, venous blood specimens were collected in the median cubital vein by folding the elbow by $5 \mathrm{ml}$. Next blood is sent to the laboratory for examination leptin levels. Examination of leptin levels using reagents from the Human LEP (leptin) ELISA kit (Catalog No: E-EL-H0113, R\&D System, USA). How to measure BMI before pregnancy is by asking the patient the weight and height of the patient before the detection of pregnancy. In this study, patients were not followed up until birth.

\section{RESULT}

The study was conducted on 69 patients consisting of 23 early-onset preeclampsia, 23 lateonset preeclampsia and 23 normal pregnancies. Sample characteristic of 69 patients, based on age, gestational age, parity, systole and diastole blood pressure, body mass index (BMI), and birth weight was shown in Table 1.

Table 1. Clinical characteristics of the study population

\begin{tabular}{lccc}
\hline \multicolumn{1}{c}{ Characteristics } & \multicolumn{2}{c}{ Preeclampsia Onset } & \multirow{2}{*}{ Normal Pregnancy } \\
\hline EOPE of pregnant women (year) & $32.35 \pm 7.33$ & $32.96 \pm 6.88$ & $29.30 \pm 2.18$ \\
Gestation age (week) & $29.04 \pm 3.37$ & $36.91 \pm 2.04$ & $38.22 \pm 0.67$ \\
Parity (\%) & & & \\
$\quad$ Nullipara & 34,8 & 39,1 & 4,3 \\
$\quad$ Multipara & 65,2 & 60,9 & 95,7 \\
Sistolic (mmHg) & $169.35 \pm 20.90$ & $160.43 \pm 17.18$ & $114.78 \pm 5.11$ \\
Diastolic $\mathrm{mmHg})$ & $103.61 \pm 12.32$ & $100 \pm 9.53$ & $73.48 \pm 4.87$ \\
BMl before pregnancy $\left(\mathrm{kg} / \mathrm{m}^{2}\right)$ & $28.52 \pm 5.06$ & $28.76 \pm 6.04$ & $25.08 \pm 1.69$ \\
BMl during pregnancy $\left(\mathrm{kg} / \mathrm{m}^{2}\right)$ & $32.18 \pm 4.84$ & $35.10 \pm 6.56$ & $31.02 \pm 1.96$ \\
\hline
\end{tabular}

Based on the table, it is known that early onset and late onset preeclampsia have respondents with almost the same age average of 32 years, whereas in normal pregnancy the average age is 29 years. In the early onset preeclampsia group, the systolic blood pressure is higher than the late onset preeclampsia and normal pregnancy $(169.35 \pm 20.90$ vs $160.43 \pm$ 17.18 vs. $114.78 \pm 5.11$ ). The diastole blood pressure found in the early onset preeclampsia group was higher than late onset preeclampsia and normal pregnancy (103.61 \pm 12.32 vs 100 \pm 9.53 vs $73.48 \pm 4.87$ ). In the late onset preeclampsia group, the mean BMI before pregnancy was higher compared with early onset and normal pregnancy ( $28.76 \pm 6.04$ vs $28.52 \pm 5.06$ vs. 


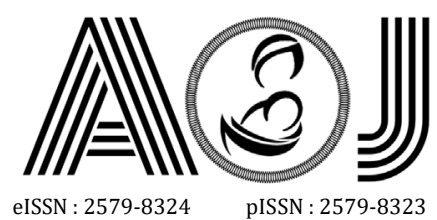

eISSN : 2579-8324
pISSN : 2579-8323
ANDALAS OBSTETRICS AND GYNECOLOGY JOURNAL

Alamat Korespondensi:

Ruang Redaksi Andalas Obstetrics and Gynecology Journal, Lantai 3 PPDS Obstetri dan Ginekologi Universitas Andalas, RSUP DR. M. Djamil Padang, Jl. Perintis Kemerdekaan Padang, Sumatera Barat 25127

Website:

http://jurnalobgin.fk.unand.ac.id/index.php/JOE

$25.08 \pm 1.69$ ). Similar results were also found for BMI during pregnancy ( $35.10 \pm 6.56$ vs 32.18 \pm 4.84 vs $31.02 \pm 1.96)$.

Table 2: Leptin Levels and the onset preeclamsia

\begin{tabular}{ccccc}
\hline \multirow{2}{*}{ Variable } & \multicolumn{3}{c}{ Preeclampsia Onset } & \multirow{2}{*}{ P-value } \\
\cline { 2 - 4 } & $\operatorname{EOPE}(\mathrm{n}=23)$ & LOPE $(\mathrm{n}=23)$ & Normal $(\mathrm{n}=23)$ & \\
\hline Leptin $(\mathrm{ng} / \mathrm{ml})$ & $64.07 \pm 78.27$ & $30.46 \pm 31.99$ & $16.61 \pm 24.49$ & 0.008 \\
\hline
\end{tabular}

From the statistical results obtained $p$ value $=0.008(p$ value $<0.05)$ then there is $a$ significant correlation between leptin levels with the onset of preeclampsia, it is known that Leptin levels are higher in early onset preeclampsia compared to late onset preeclampsia and late onset preeclampsia normal pregnancy. The results of the study showed that the mean leptin level in early onset preeclampsia was higher than late onset preeclampsia and normal pregnancy which was $64.07 \pm 78.27$ vs $30.46 \pm 31.99$ vs $16.61 \pm 24.49$. There was a statistically significant correlation $(p<0.05)$ between leptin levels and the onset of preeclampsia. The results of this study are in line with studies conducted by Tessier et al (2013) that there are increased levels of leptin in the circulation, expression of placental leptin genes and levels of leptin protein in preeclampsia compared to normal pregnancy. ${ }^{13}$ Likewise, research conducted by Yusrawati et al (2015) found that plasma leptin levels increased significantly in preeclampsia compared to normal pregnancy. ${ }^{10}$ Research by Salimi et al (2014) found higher leptin levels in early onset preeclampsia than in late onset preeclampsia. ${ }^{2}$ However, research by Molvarec et al (2011) reported that there was no significant difference between leptin levels and the onset of preeclampsia. ${ }^{14}$

The effect of increased leptin on preeclampsia is still not fully proven. Beneficial and detrimental effects may occur when an increase in leptin in preeclampsia. In preeclampsia, an increase in leptin beyond a normal pregnancy may be an attempt to overcome the resistance of leptin to the placenta and improve the availability of placental nutrition. Another theory says that the increase in leptin in preeclampsia may be an attempt to increase placental growth through increased angiogenesis, because leptin is an angiogenic factor. Although the presence of leptin receptors in endothelial cells in the human placenta cannot yet be detected, leptin may indicate its angigenic role indirectly through stimulation of other angiogenic factors, such as VEGF or PLGF. ${ }^{15.16}$ According to Poston (2002) concluded that several processes that can occur due to increased leptin, including increased sympathetic nerve activity, mitochondrial superoxide synthesis, Th1 cell expansion secretes proinflammatory cytokines, and activates the expression of metalloproteinases and inhibitors of metalloproteinase matrix networks that modulate vascular structures.16 All of these processes contribute to oxidative stress, placental and endothelial dysfunction and ultimately lead to preeclampsia. ${ }^{1}$ 


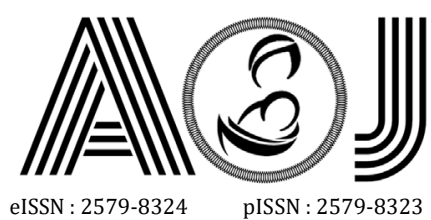

eISSN : 2579-8324
pISSN : 2579-8323

Ruang Redaksi Andalas Obstetrics and Gynecology Journal, Lantai 3 PPDS Obstetri dan Ginekologi Universitas Andalas, RSUP DR. M. Djamil Padang, Jl. Perintis Kemerdekaan Padang, Sumatera Barat 25127

Website:

http://jurnalobgin.fk.unand.ac.id/index.php/JOE

\section{CONCLUSION}

The correlation between leptin levels with the onset of preeclampsia was found to be the highest level in early onset preeclampsia, which was $64.07 \pm 78.27$. There was a significant correlation $(p<0.05)$ between leptin levels and the onset of preeclampsia.

\section{REFERENCES}

1. Rigo J, Szendei G, Rosta K, et al. 2006. Leptin receptor gene polymorphisms in severe preeclampstia women. Gynecological Endocrinology22(9): 521-525

2. Salimi S, Mashhadi FF, Naghavi A, et al. 2014. Different profile of serum leptin between early onset and late onset preeclampsia. Hindawi Publishing Corporation Disease Markers2014: 1-7

3. Cunningham FG, et al. 2014. Hypetensive disorder in pregnancy. Dalam William Obstetric 23 ed. New York: McGraw-Hill Companies Inc

4. Mackay AP, Berg CJ, Atrash HK. 2001. Pregnancy-related mortality from preeclampsia and eclampsia. Obstet Gynecol 97(4):533-538

5. Von Dadelszen P, Magee LA, Roberts JM. 2003. Subclassification of preeclampsia. Hypertens pregnancy 22(2): 143-148

6. Ogge G, Chaiworapongsa T, Romero R, et al. 2011. Placental lesions associated with maternal underperfusion are more frequent in early onset than late onset preeclampsia. Journal of Perinatal Medicine 3(6):641-652

7. Sulistyowati S. 2017. Early and late onset preeclampsia: what did really matter?. Journal of Gynecology and Women's Health 5(4): 1-3

8. Roberts J. 2009. Pregnancy related hypertension. In (Creasy R, Resnik R, lams JD, editors) maternal-fetal medicine: principles and practice 6. Philadelphia: Saunders Elsevier, pp 650-88

9. Laivuori H, Gallaher MJ, Collura L, et al. 2006. Relationships between maternal plasma leptin, placental leptin mRNA and protein in normal pregnancy, preeclampsia and intrauterine growth restriction without preeclampsia. Mol Hum Reprod 12:551556

10. Yusrawati, Habibah RL, Machmud R. 2015. Differences in maternal leptin serum levels between normal pregnancy and preeclampsia. Indones Biomed 7(1): 37-42

11. Anim-Nyame, Sooranna SR, Steer PJ,Johnson MR. 2000. Longitudinal analysis of maternal plasma leptin concentration during normal pregnancy and pre-eclampsia. Human Reprod 15: 2033-2036

12. El Shahat AM, Ahmed AB, Ahmed MR, Mohamed HS. 2013. Maternal serum leptin as a marker of preeclampsia. Arch Gynecol Obstet 288(6):1317-1322 


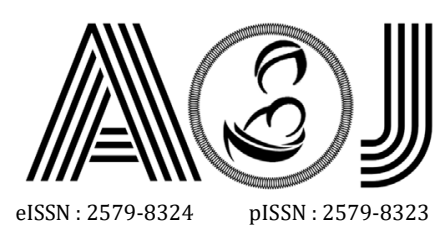

elSSN : 2579-832

Ruang Redaksi Andalas Obstetrics and Gynecology Journal, Lantai 3 PPDS Obstetri dan Ginekologi Universitas Andalas, RSUP DR. M. Djamil Padang, Jl. Perintis Kemerdekaan Padang, Sumatera Barat 25127

13. Tessier DR, Ferraro ZM, Gruslin. 2013. Role of leptin in pregnancy:consequences of maternal obesity. Plasenta 34: 205-211

14. Molvarec A, Szarka A, Walentin S, et al. 2011. Serum leptin level in relation to circulating cytokines, chemokines, adhesion molecules and angigenic factor in normal pregnancy and preeclampsia. Reproductive Biology and Endocrinology 9: 124

15. Hoggard N, Hagarty P, Thomas L, Lea RG. 2001. Leptin expression in placental and fetal tissues: does leptin have a functional role?. Biochemical Society Transactions 29(2): 57-63

16. Poston L. 2002. Leptin and preeclampsia. Seminars in Reproductive medicine 20(2): 131-138 